УДК 364-787.24:343.62-055.2

DOI https://doi.org/10.32782/humanitas/2021.5.12

\title{
Галина СКІПАЛЬСЬКА
}

виконавчий директор, Міжнародний благодійний фонд «Украӥнська фундаиія громадського здоров 'я», вул. Володимирська, 43, м. Київ, Украӥна, 01034

ORCID: 0000-0002-5215-5480

\section{Тетяна ЛЯХ}

кандидат педагогічних наук, дочент, завідувач кафедри соиіальної педагогіки та соиіальної роботи, Інститут людини Київського університету імені Бориса Грінченка, бульвар I. Шамо, 18/2, м. Київ, Україна, 02154

ORCID: 0000-0002-8807-0497

Scopus-Author ID: 57192588245

\section{Наталія КЛНЕВИЧ}

кандидат педагогічних наук, доцент, директор, Інститут людини Київського університету імені Бориса Грінченка, бульвар I. Шамо, 18/2, м. Київ, Украӥна, 02154

ORCID: 0000-0002-5611-6454

Scopus-Author ID: 57192578310

Бібліографічний опис статті: Скіпальска, Г., Лях, Т., Клішевич, Н. (2021) Жінки, які постраждали від домашнього насильства, як об'єкт соціальної роботи. Bвічливість. Humanitas, 5 , 82-89, doi: https://doi.org/10.32782/humanitas/2021.5.12

\section{ЖІНКИ, ЯКІ ПОСТРАЖДАЛИ ВІД ДОМАШНЬОГО НАСИЛЬСТВА ЯК ОБ'ЄКТ СОЦІАЛЬНОЇ РОБОТИ}

У сучасній соизільній роботі однією з найбільи незахищених верств населення є діти, захист яких є основоположною стратегією держав. Водночас є низка категорій осіб, хто потребує негайного й особливого захисту (внутрішньо переміщені особи, військовослужбовці, їхні сім'ї тощь). У розрізі всіх соціальних змінних серед усіх категорій отримувачів послуг жінки лишаються тією категорією, щцо вирізняється з інших. Тому автори статті розглядають саме жінок як об'єкт сочіальної роботи, зокрема тих жінок, які постраждали від домашнього насильства.

Проблема насильства щзодо жінок є однією з актуальних дослідницьких проблем у галузі соиіальної роботи.

Насильство перешкоджає повноцінній участі жінок у житті суспільства, має довгострокові наслідки та витрати для сімей жінок, громад та краӥн. Будучи грубим порушенням прав людини, насильство щзодо жінок і дівчат залишається широко поширеним явищем в Свропі та Центральній Азії. Україна не є винятком.

Жінки, які зазнали домашнього насильства, - це жінки, які потрапили у складну життєву ситуацію i потребують допомоги та реабілітації, якою займаються фахівиі із соиіальної роботи. Для надання допомоги жінкам, які постраждали від насильства, організації профілактичних заходів потрібні високопрофесійні, кваліфіковані фахівиі, які мають глибокі теоретичні знання та практичний досвід роботи. Проте одних теоретичних знань замало, потрібне постійне вдосконалення, практична робота з розв 'язання кризових ситуацій, зумовлених насильством, стажування з урахуванням діючих соціальних иентрів під керівництвом досвідчених супервізорів. Потрібна розробка різних, багатопрофільних технологій соціальної роботи з жінками, оскільки надзвичайно важливо, щуоб жінки, які постраждали від жорстокого поводження в сім'ї, мали змогу отримувати повну інформацію з юридичних та правових питань, психологічну підтримку.

Ключові слова: жінки, жінки, які постраждали від домашнього насильства, насильство, домашнє насильство. 


\section{Halyna SKIPALSKA}

Executive Director, Ukrainian Foundation for Public Health, 43 Volodymyrska str., Kyiv, Ukraine, 01034

ORCID: 0000-0002-5215-5480

\section{Tetiana LIAKH}

PhD in Education, Associate Professor, Head of Social Pedagogy and Social Work Department, Institute of Human Sciences of Borys Grinchenko Kyiv University, 18/2 I. Shamo Boulevard, Kyiv, Ukraine, 02154

ORCID: 0000-0002-8807-0497

Scopus-Author ID: 57192588245

\section{Nataliia KLISHEVYCH}

PhD in Education, Associate Professor, Director, Institute of Human Sciences of Borys Grinchenko Kyiv University, 18/2 I. Shamo Boulevard, Kyiv, Ukraine, 02154

ORCID: 0000-0002-5611-6454

Scopus-Author ID: 57192578310

To cite this article: Skipalska, H., Liakh, T. (2021) Zhinky, yaki postrazhdaly vid domashnoho nasylstva, yak obiekt sotsialnoi roboty [Women survivors of domestic violence as objects of social work]. Vvichlyvist. Humanitas, 5, 82-89, doi: https://doi.org/10.32782/humanitas/2021.5.12

\section{WOMEN SURVIVORS OF DOMESTIC VIOLENCE AS OBJECTS OF SOCIAL WORK}

In modern social work, children are considered one of the most vulnerable populations, and their protection is a highpriority strategy for states. However, there are other populations who need immediate and specific support (internally displaced persons, military personnel, their families, etc.). In terms of all social variables, among all categories of recipients of social services, women belong to the category that differs from others. Therefore, the authors of the article study women as objects of social work, specifically, women survivors of domestic violence.

Violence against women is one of the most relevant research topics in the field of social work.

Violence restricts the full participation of women in society, has long-term consequences and expenses for women's families, communities, and countries. As a gross violation of human rights, violence against women and girls remains widespread in Europe and Central Asia. Ukraine is no exception.

Women survivors of domestic violence are women who have found themselves in a difficult life situation and seek help and rehabilitation services from social workers. Highly professional, qualified specialists with deep theoretical knowledge and practical skills are needed to provide support to women survivors of violence and arrange preventive measures. However, theoretical knowledge alone is not enough; life-long learning, improvement of practical skills of responding to crises caused by violence, and professional development under the guidance of experienced supervisors on site of existing social centers are required. It is necessary to develop various, multidisciplinary technologies of social work with women, as it is crucial that women survivors of domestic violence can receive complete legal information and legal aid, psychological counseling.

Key words: adolescents, juveniles, minors in conflict with the law, socio-pedagogical support.

Постановка проблеми. В Україні нині збільшується кількість неповнолітніх, які перебувають у конфлікті із законом, оскільки економічні, соціально-політичні, демографічні зміни сприяють знеціненню системи цінностей, соціальних зв’язків та відносин. Дослідження питання соціально-педагогічної підтримки неповнолітніх, які перебувають у конфлікті із законом, вимагає значної уваги, адже в багатьох випадках саме дезадаптація підлітків стає поштовхом до протиправних вчинків.

Суспільство має свою систему норм та правил, що містять вимоги до поведінки й обов'язків кожного члена суспільства. I соціальні проблеми як сприяють виникненню складних життєвих ситуацій, вирішуючи які, людина порушує прийняті норми, так і впливають на формування особистості. Саме особистісні якості утруднюють оцінку ситуації, не дають змоги прийняти адекватне, відповідальне рішення, свідомо управляти своєю поведінкою та протистояти негативному впливу сторонніх осіб. Крім того, $\epsilon$ ймовірність, що протиправна поведінка підлітків згодом обертається в кримінальні форми поведінки й може становити небезпеку як для неповнолітнього, так і для найближчого оточення та всього суспільства загалом. Труднощі, які $є$ актуальними в Україні, характерні для 
багатьох зарубіжних країн, адже не можна стверджувати, що усі завдання соціально-педагогічної підтримки успішно вирішені, наприклад, рівень злочинності серед неповнолітніх все ще залишається доволі актуальним.

Аналіз досліджень. Аналіз наукової літератури засвідчив, що останніми роками насильство над жінками та його причини розглядаються широким колом науковців і в нашій країні. Зокрема, вивчаються історія та розвиток явища домашнього насильства над жінками (Сукмановська, 2016; Рутьян, 2021; Спіріна, Грицуняк, 2019, та ін.), сутність поняття та види домашнього насильства, психологічні детермінанти домашнього насильства над жінками (Циганчук, Лях, 2014; Шиделько, 2020 та ін.), криміналізація насильства над жінками (Запорожець, 2018; Чайка, 2018 та ін.), соціальні, юридичні, економічні та психологічні аспекти домашнього насильства (Лукач, 2017; Зінсу, 2020), попередження насильства над жінками (Малиновська, 2016) та ін.

Мета статті. Незважаючи на існування значної кількості наукових праць, присвячених проблемам запобігання насильству над жінками, це явище залишається маловивченим, що й зумовило необхідність розглянути цю категорію отримувачів соціальних послуг як об'єкт соціальної роботи.

Виклад основного матеріалу. Нерідко права жінок порушуються не з боку держави, а саме з боку членів іiі сім’ї. У Загальній декларації прав людини містяться положення, які стосуються захисту прав людини на створення сім'ї і вступу в шлюб: «Ніхто не може зазнавати безпідставного втручання в його особисте й сімейне життя, безпідставного посягання на недоторканність його житла, таємницю його кореспонденції або на його честь і репутацію. Кожна людина має право на захист закону від такого втручання або таких посягань» (стаття 12). У статті 16 йдеться про те, що «чоловіки й жінки <..> користуються однаковими правами щодо одруження, під час перебування в шлюбі та під час його розірвання; сім'я $\epsilon$ природним та основним осередком суспільства й має право на захист із боку суспільства й держави» (Загальна декларація прав людини, 1948).

Водночас, як зазначає К. Левченко, автор монографії «Права жінок: зміст, стан та перспективи розвитку», інститут сім'ї є сферою, де найчастіше використовується історично сформоване співвідношення статей. У сім'ї, 3 одного боку, можуть і повинні розвиватися позитивні процеси турботи й опіки, при яких люди пов'язані почуттями, а з іншого боку, сім'я може бути соціальним інститутом, де порушуються права жінок, виявляється насильство над жінками й дітьми (Левченко, 2001).

За таких обставин можна говорити про гендерну нерівність, яка в соціології трактується як «гендерна асиметрія». Якщо звертатися до «Словника гендерних термінів», то гендерну асиметрію варто розглядати як непропорційність соціальних та культурних ролей або уявлень чоловіків та жінок у різних сферах життя (Денисова, 2002).

Водночас ми не зупиняємося виключно на гендерних установках та не розмежовуємо права жінок та чоловіків у всіх сферах суспільства. Акцент нашого дослідження спрямований саме на сімейно орієнтовану модель, де права жінки в разі загрози їй можуть бути захищеними. Захист жінки в соціальній роботі $є$ вкрай важливим, адже він передбачає й захист дитини, що $€$ основною метою в процесі роботи із сім'єю.

Розглядаючи сім'ю 3 практичної сторони, фахівці зіштовхуються 3 низкою актуальних проблем. Зокрема, йдеться про насильство в сім'ї, домашнє насильство, особливо щодо жінок. Попри численні дослідження, напрацювання та розробку різних методів соціальнопсихологічної роботи як із постраждалою, так iз кривдником, ці питання залишаються кричущими в українських реаліях. Також, незважаючи на грунтовну законодавчу базу в питаннях захисту щодо насильства, держава не завжди спроможна захистити жінку та їі дитину або вчасно посприяти наданню їм відповідної допомоги. Дієвим ресурсом у допомозі жінкам, які постраждали від домашнього насильства, є неурядові організації, які вміло працюють із міжнародною базою (документами, пактами, положеннями, моделями тощо) щодо жіночих людських прав та запобігання насильству щодо жінок, а також можуть швидко реагувати на соціальну проблему.

Проблема насильства над жінками, на жаль, зумовлена усталеними традиціями, звичаями та нормами, які існували сторіччями в українських сім'ях. Не можна не згадати і про наслідки соціального тиску: почуття сорому, відсутністю 
в жінок доступу до юридичної інформації, допомоги або захисту; недосконалістю законів, які фактично забороняють насилля щодо жінок та карають кривдників; нездатністю реформувати наявне законодавство; недостатніми зусиллями з боку державних органів щодо сприяння розповсюдженню інформації про наявні закони й забезпеченню їх дотримання; відсутністю просвітницьких та інших заходів 3 усунення причин та наслідків насилля (Левченко, 2001).

Серед чинників, що призводять до домашнього насильства, або неможливості йому протистояти, вирізняють такі:

- соиіально-культурні (дотримання хибних, застарілих традицій та звичаїв, що укорінені в українському суспільстві; стереотипність уявлень щодо розподілу ролей у сім'ї та виховання, позиція передавання виховної функції матері, виключаючи чоловіка, відносна терпимість соціуму до проявів домашнього насильства, вплив 3МІ, що відображається в неправильному формулюванні понять під час висвітлення сюжетів, тощо);

- психологічні (психічні розлади, високий рівень агресії, власний негативний досвід дитинства, низька самооцінка осіб, можливі страхи та тривога за своє майбутнє та майбутнє дітей, невміння вибудовувати власну позицію щодо своєї сімейної ролі тощо);

- сочіально-економічні (зниження рівня життя частини населення, безробіття або низький трудовий статус, соціально-побутова невлаштованість, фінансова залежність одного члена сім'ї від іншого, відсутність фінансової грамотності тощо).

Варто зазначити, що саме насильство $€$ одним із головних механізмів, що ставлять жінок у підпорядковану позицію порівняно з чоловіками. У Декларації про викорінювання насилля щодо жінок, прийнятою ООН в 1993 році, проголошується необхідність захисту прав жінок від будь-яких форм насильства: фізичного, психічного, економічного, політичного, культурного (Декларація про викорінювання насилля щодо жінок, 1993).

У розрізі мети нашої статті актуальності набуває саме домашнє насильство, адже саме воно має прихований зміст, замовчування, що згодом формує в жертви депресивні стани, страхи, апатію, відсутність сил боротися за власне життя тощо. Домашнє насильство - це той вид насильницьких дій, які важко підтвердити та довести, часто-густо саме через приховування їх саме жінкою. Варто враховувати й той факт, що це проблема всієї сім'ї, не лише жінки як основного об'єкта соціальної роботи в цьому випадку.

Закон України «Про запобігання та протидію домашньому насильству» домашнє насильство розглядає як діяння (дії або бездіяльність) фізичного, сексуального, психологічного або економічного насильства, що вчиняються в сім'ї чи в межах місця проживання або між родичами, або між колишнім чи теперішнім подружжям, або між іншими особами, які спільно проживають (проживали) однією сім'єю, але не перебувають (не перебували) у родинних відносинах чи у шлюбі між собою, незалежно від того, чи проживає (проживала) особа, яка вчинила домашне насильство, в тому самому місці, що й постраждала особа, а також погрози вчинення таких діянь (Про запобігання та протидію домашньому насильству, 2017).

Ознаками, які вказують на наявність насильницьких дій, є: навмисність; фізична, сексуальна, психологічна чи економічна спрямованість дій, які можуть виявлятися як у комплексі, так і кожна 3 дій окремо; порушення конституційних прав людини («невід’ємне право на життя», «право на повагу до його гідності», «право на свободу та особисту недоторканність», прав на особисте життя, «право на володіння, користування й розпорядження своєю власністю», «право на працю», «кожен із подружжя має рівні права й обов'язки в шлюбі та сім'ї» тощо); наслідки на рівні завдання моральної та фізичної шкоди, шкоди психічному здоров'ю тощо.

Дослідники А. Войтовська та О. Кравченко зазначають, що насильство, що розглядається в контексті домашнього насильства, має свої особливості, а саме: це не одноразова дія, це процес, який складається із циклів насильства, які тримаються на продовженні стосунків потерпілої і кривдника; якщо насильство виявилось у сім'ї хоч один раз, воно обов'язково повториться; таке насильство завжди відбувається впродовж тривалого проміжку часу й має тенденцію до зростання; це насильство між особами, де жінка, як правило, повністю залежить від чоловіка; найчастіше домашнє насильство замовчується і приховується обома сторонами від оточуючих (Войтовська, Кравченко, 2018).

Домашнє насильство постає як соціальне явище, 3 яким бореться все суспільство. 
Цивілізаційний світ не приймає вже такі застарілі стереотипні форми на кшталт: «закритість сім'ї», «проблеми сім'ї - це лише проблеми сім'ї», «б’€, значить, любить» тощо.

Розглядаючи питання насильства щодо жінок, варто звернути увагу й на права жінки, пов'язані 3 материнством. Адже, як показує практика, у випадку насильства дотичними можуть й $є$ діти, права яких теж мають бути захищеними. За таких обставин доречно розглядати й захист жінки щодо іiї репродуктивної автономії.

Так, під час Всесвітньої конференції зі становища жінок (Пекін, 1995 р.) було узгоджено, що права людини-жінки містять у собі їі право здійснювати контроль над питаннями, що стосуються сексуального поводження, включаючи сексуальне й репродуктивне здоров'я, вільно і відповідально приймати щодо них рішення без будь-якого примусу, дискримінації й насильства. Рівні взаємовідносини жінок і чоловіків у питаннях сексуальних відносин і репродуктивного поводження, в тому числі повна повага недоторканності особи, потребують взаємної поваги, згоди і загальної відповідальності за сексуальне поводження і його наслідки (Пекинская платформа действий, 1995).

Відповідно, аналіз питань щодо дискримінації жінок, здійснення щодо них насильницьких дій, декларування основних прав та свобод жінок дає підстави стверджувати, що саме жінки, які постраждали від домашнього насильства, є тим об’єктом соціальної роботи, що потребує підтримки та, власне, соціального захисту. Адже, наряду із захистом жінки, потрібен і захист дитини, що є взаємопов'язаними процесами у відтворенні соціально-активного життя матері та дитини.

Соціальний захист та підтримка таким жінкам в Україні насамперед здійснюється державою та іiі підвладними одиницями. Але одним із критеріїв надання кваліфікованої підтримки жертвам домашнього насилля вважається взаємодія між усіма відомствами держави та між фахівцями, що містить виявлення, перенаправлення та надання послуг жінкам, які постраждали від насилля, та чоловікам, які вчинили насильство (Liakh, Spirina \& Rohozhynska, 2020).

Загалом нині в Україні сформована достатньо дієва база нормативно-правового забезпечення щодо протидії насилля в сім’ї. Однак це не означає, що система захисту жінок у разі насильства не потребує змін. Уваги заслуговують і певні поняття, які можуть бути удосконаленими, а також потреба $\epsilon$ й у регулюванні механізмів виявлення та реагування на випадки насильства.

Дієвим зрушенням щодо подолання проблеми насильства в родині було ухвалення Верховною Радою України в грудні 2017 року Закону «Про запобігання та протидію домашньому насильству» (набув чинності 7 січня 2018 року), в якому запропоновано інноваційний підхід з урахуванням європейських стандартів щодо боротьби 3 таким негативними явищем (Про запобігання та протидію домашньому насильству, 2017). Цей закон розширює коло тих, хто має реагувати на випадки домашнього насилля, зокрема, це й центри 3 надання безоплатної вторинної правової допомоги, прокуратура, уповноважені з питань пробації, суди, поліція.

Послуги таким особам можуть надавати і центри соціальних служб, притулки для жінок, кризові консультативні центри, центри денного перебування та мобільні бригади. Водночас створені й групи взаємопідтримки та самодопомоги. Розроблено та впроваджено превентивні, навчально-тренінгові, психотерапевтичні програми (індивідуальні та групові). Також проводиться робота 3 правоохоронними органами тощо. Кожен суб'єкт має власний функціонал обов'язків, здійснює свої функції відповідно чинного законодавства, надає послуги відповідно до потреб жінок.

Загалом до органів та установ, на які покладається здійснення заходів щодо запобігання насильства в сім'ї, належать (Про запобігання та протидію домашньому насильству, 2017) спеціально уповноважений орган виконавчої влади 3 питань запобігання насильства в сім'і, яким визначено Міністерство соціальної політики України, а також відповідні управління місцевих державних адміністрацій, відповідні підрозділи органів внутрішніх справ, до яких належать служба дільничних інспекторів поліції та кримінальна поліція у справах дітей органів внутрішніх справ, органи опіки та піклування, спеціалізовані служби підтримки постраждалих осіб, до яких належать (притулки для постраждалих осіб, центри медико-соціальної реабілітації постраждалих осіб, кол-центр із питань запобігання та протидії домашньому насильству, насильству за ознакою статі та насильству стосовно дітей, мобільні бригади соціально- 
психологічної допомоги постраждалим особам та особам, які постраждали від насильства за ознакою статі, а також заклади та установи, призначені виключно для постраждалих осіб та осіб, які постраждали від насильства за ознакою статі).

Якщо розмежовувати різні категорії надавачів соціальних послуг, то їх можна поділяти на державні структури і неурядові організації.

Державні структури є ефективними для мобілізації інтенсивного впливу. Вони надають загальну кількість соціальних послуг та здійснюють підтримку незахищених верств населення. Якість надання соціальних послуг може містити не так якісні показники, як переважатимуть в їхній діяльності кількісні результати роботи.

Водночас європейська практика спирається на інших надавачів послуг - громадські недержавні організації та місцеві громади, які в останні роки збільшили свою спроможність у здійсненні соціальної підтримки. Перевагою громадських та благодійних організацій є їхня здатність надавати послуги екстреніше та з розрахунком на конкретний об'єкт діяльності.

Соціальна робота, зокрема, 3 жінками, які зазнали насильства в сім'ї, базується на принципах екосистемності, полімодальності, солідарності, конструктивної стимуляції, континуальності (Белова, Акутина, 2019).

Як вже згадувалося на початку статті, домашнє насильство часто може мати прихований характер. Не тільки гвалтівник, а й жертва нерідко докладає всіх зусиль, щоб приховати ситуацію: через почуття сорому, зі страху, або через відчуття безпорадності, неможливості щось змінити на краще, а іноді просто через незнання. Тому проблема виявлення випадків і причин домашнього насильства та формування активної установки на зміну сценарію - це складне та важливе професійне завдання фахівців із соціальної роботи, що потребує високого рівня кваліфікації, уміння налагодити контакт та створити атмосферу безпеки та довіри.

Принциповим завданням, яке нерідко доводиться вирішувати, виявляється діагностика ситуації. Також у ситуації домашнього насильства фахівцям із соціальної роботи доводиться вирішувати, як мінімум, такі завдання: просвітницькі, навчальні; діагностичні; терапевтичні; консультативні; організаційні; адміністративні.
Можна виділити кілька стратегічних завдань фахівцязіз соціальної роботи.

По-перше, це подолання неусвідомлених захисних механізмів жінки, яка постраждала від домашнього насильства, заперечення, які блокують доступ до проблеми. Для цього необхідне створення безпечної атмосфери і підвищення сили «Я», щоб воно змогло перенести вивільнені з підсвідомості нестерпні передусім переживання.

По-друге, це формування системи підтримки жінки, яка постраждала від домашнього насильства, частину якої можуть становити соціальний працівник та терапевт, друзі, близькі, улюблені заняття та тварини.

По-третє, побудова системи для подолання кризи - списку телефонів кризових служб, фахівців, людей, до яких можна звернутися, коли щось трапляється, втрачається впевненість, стає страшно, виникає розгубленість.

Як додаткове, але принципово важливе, можна виділити ще одне завдання фахівця із соціальної роботи - забезпечення психологічного самозахисту, що дозволяє йому не стати об'єктом маніпуляцій отримувачів послуг та їхніх родичів й уникнути професійного вигоряння, оскільки ситуації домашнього насильства дуже заряджені емоційно та непросто.

Більше того, соціальні працівники перебувають у групі ризику ще й тому, що вибору цієї професії сприяє низка особистісних властивостей, які створюють сприятливі умови для виникнення таких проблем (наприклад, формування співзалежності).

Висновки. Отже, можна стверджувати, що узгоджений міжвідомчий зв'язок державних соціальних установ, органів охорони здоров'я, спеціалізованих соціальних служб, неурядових організацій відіграє велику роль у процесі надання безпосередньої допомоги жінкам, які зазнали насильства в сім’ї. Варто також зазначити, щоб усі компоненти цієї системи взаємодіяли у близькому контактному середовищі, а жертви насильницьких дій могли розраховувати на повне всебічне сприяння та своєчасну допомогу та підтримку фахівців цих організацій. Фахівець із соціальної роботи займає провідну позицію в цьому процесі, тому що саме він має організувати дієву взаємодію державних і недержавних установ щодо вирішення проблеми жорстокого поводження 3 жінками, які зазнали насильства в сім’ї. 


\section{ЛIТЕРАТУРА:}

1. Белова О.Н., Акутина С.П. Женское насилие в семье как социальная проблема. Социодинамика. 2019. Т. 3 , № 3. C. 18-26. URL: https://doi.org/10.25136/2409-7144.2019.3.29282 (дата звернення: 25.11.2021).

2. Войтовська А.І., Кравченко О.О. Соціальна робота з жінками. Умань : Візаві, 2018. 229 с.

3. Декларація про викорінювання насилля щодо жінок, Декларація Організації Об'єднаних Націй (1993). URL: https://zakon.rada.gov.ua/laws/show/995_506\#Text

4. Словарь гендерных терминов / под ред. А. Денисовой. Москва : Информация XXI век, 2002. 256 c.

5. Загальна декларація прав людини : Декларація Організації Об'єднаних Націй від 10.12.1948 p. URL: https://zakon.rada.gov.ua/laws/show/995_015\#Text (дата звернення: 26.11.2021).

6. Запорожець А. Криміналізація домашнього насильства - новела кримінального законодавства України. Вісник кримінального судочинства. 2018. № 1. С. 148-154.

7. Зінсу О. Соціальні та юридично-психологічні аспекти домашнього насильства. Науковий вісник Наиіональної академії внутрімніх справ. 2020. № 1 (114). C. 79-87. URL: https://doi.org/10.33270/01201141.79 (дата звернення: 25.11.2021).

8. Левченко К.Б. Права жінок: зміст, стан та перспективи розвитку. Харків : Вид-во НУВС, 2001. 360 с.

9. Лукач У. Теоретичні аспекти проблеми економічного насильства над жінками. Теоретичні, методичні та практичні проблеми соиіальної роботи : тези доповідей II Всеукраїнської з міжнародною участю науково-практичної конференції, Івано-Франківськ, 6 квітня 2017 р. Івано-Франківськ : НАIP, 2017. С. 216-218.

10. Лях Т., Спіріна Т., Рогожинська В. Принципи міждисциплінарної взаємодії у соціальній роботі. Huтаnities science current issues. 2020. Т. 3, № 27. C. 224-228. URL: https://doi.org/10.24919/2308-4863.3/27.203727 (дата звернення: 29.11.2021).

11. Малиновська Т.М. Попередження насильства над жінками в сім'ї. Право і Безпека. 2016. № 1. С. 117-120.

12. Пекинская платформа действий. Итоговый документ Четвертой Всемирной конференции ООН по положению женщин. ООН, 1995. 66 с.

13. Про запобігання та протидію домашньому насильству : Закон України від 07.12.2017 p. № 2229-VIII : станом на 1 січ. 2020 p. URL: https://zakon.rada.gov.ua/laws/show/2229-19\#Text (дата звернення: 29.11.2021).

14. Психологічні детермінанти домашнього насильства над жінками. Актуальні проблеми психології : збірник наукових праць Інституту психології імені Г. С. Костюка НАПН України. 2018. С. 265-273.

15. Рутьян Л. Історія і розвиток домашнього насильства над жінкам як наукового поняття. Молодь $і$ ринок. 2021. № 5/191. URL: https://doi.org/10.24919/2308-4634.2021.232824 (дата звернення: 25.11.2021).

16. Спіріна Т.П., Грицуняк І.С. Військовослужбовці-жінки: виклик стереотипам. Педагогічні науки. 2019. № 87. C. 189-192. URL: https://doi.org/10.32999/ksu2413-1865/2019-87-34 (дата звернення: 29.11.2021).

17. Сукмановська Л. Історичні аспекти виникнення домашнього насильства. Науковий вісник Львівського державного університету внутрішніх справ. 2016. Т. 3. 272-281.

18. Циганчук Т., Лях Д. Насильство над жінками в сімейних стосунках. Практична психологія та соиіальна робота. 2014. № 2. С. 65-69.

19. Чайка В.В. Соціальна зумовленість криміналізації насильства в родині. Молодий вчений. 2018. № 4 (1). C. 104-107.

\section{REFERENCES:}

1. Belova O.N., Akutyna S.P. Zhenskoe nasylye v seme kak sotsyalnaia problema. (2019). Sotsyodynamyka. 3(3), 18-26. https://doi.org/10.25136/2409-7144.2019.3.29282 [in Ukrainian]

2. Chaika V.V. (2018). Sotsialna obumovlenist kryminalizatsii nasylstva v rodyni. Molodyi vchenyi. 4 (1). 104-107. [in Ukrainian]

3. Deklaratsiia pro vykoriniuvannia nasyllia shchodo zhinok, Deklaratsiia Orhanizatsii Obiednanykh Natsii (1993). Retrieved from: https://zakon.rada.gov.ua/laws/show/995_506\#Text [in Ukrainian]

4. Denysova, A. (Red.). (2002). Slovar hendernikh termynov. Ynformatsyia KhKhI vek. [in Russian]

5. Levchenko, K.B. (2001). Prava zhinok: zmist, stan ta perspektyvy rozvytku. NUVS. [in Ukrainian]

6. Liakh, T., Spirina, T., \& Rohozhynska, V. (2020). Pryntsypy mizhdystsyplinarnoi vzaiemodii u sotsialnii roboti. Humanities science current issues, 3(27), 224-228. https://doi.org/10.24919/2308-4863.3/27.203727 [in Ukrainian]

7. Lukach U. (2017). Teoretychni aspekty problemy ekonomichnoho nasylstva nad zhinkamy. Teoretychni, metodychni ta praktychni problemy sotsialnoi roboty. 216-218. [in Ukrainian]

8. Malynovska T.M. (2016). Poperedzhennia nasylstva nad zhinkamy v simi. Pravo i Bezpeka. 1. S. 117-120. [in Ukrainian]

9. Pekynskaia platforma deistvyi (1995). Ytohovii dokument Chetvertoi Vsemyrnoi konferentsyy OON po polozhenyiu zhenshchyn. OON, 66. [in Russian] 
10. Pro zapobihannia ta protydiiu domashnomu nasylstvu, Zakon Ukrainy № 2229-VIII (2020) (Ukraina). Retrieved from: https://zakon.rada.gov.ua/laws/show/2229-19\#Text [in Ukrainian]

11. Psykholohichni determinanty domashnoho nasylstva nad zhinkamy. (2018). Aktualni problemy psykholohii : Zbirnyk naukovykh prats Instytutu psykholohii imeni H. S. Kostiuka NAPN Ukrainy, 265-273. [in Ukrainian]

12. Rutian, L. (2021). Istoriia i rozvytok domashnoho nasylstva nad zhinkamy yak naukovoho poniattia. Molod i rynok, (5/191). https://doi.org/10.24919/2308-4634.2021.232824 [in Ukrainian]

13. Spirina, T.P., \& Hrytsuniak, I.S. (2019). Viiskovosluzhbovtsi-zhinky: vyklyk stereotypam. Pedahohichni nauky, (87), 189-192. https://doi.org/10.32999/ksu2413-1865/2019-87-34 [in Ukrainian]

14. Sukmanovska, L. (2016). Istorychni aspekty vynyknennia domashnoho nasylstva. Naukovyi visnyk Lvivskoho derzhavnoho universytetu vnutrishnikh sprav, 3, 272-281. [in Ukrainian]

15. Tsyhanchuk T., Liakh D. (2014). Nasylstvo nad zhinkamy v simeinykh stosunkakh. Praktychna psykholohiia ta sotsialna robota. 2. 65-69. [in Ukrainian]

16. Voitovska, A.I., \& Kravchenko, O.O. (2018). Sotsialna robota z zhinkamy. Vizavi. [in Ukrainian]

17. Zahalna deklaratsiia prav liudyny (ros/ukr), Deklaratsiia Orhanizatsiia Obiednanykh Natsii (1948). Retrieved from: https://zakon.rada.gov.ua/laws/show/995_015\#Text [in Ukrainian]

18. Zaporozhets A. (2018). Kryminalizatsiia domashnoho nasylstva - novela kryminalnoho zakonodavstva Ukrainy. Visnyk kryminalnoho sudochynstva. 1, 148-154. [in Ukrainian]

19. Zinsu, O. (2020). Sotsialni ta yurydychno-psykholohichni aspekty domashnoho nasylstva. Naukovyi visnyk Natsionalnoi akademii vnutrishnikh sprav. 1 (114), 79-87. https://doi.org/10.33270/01201141.79 [in Ukrainian] 